\section{B A Institute of \\ YK Business Administration \\ 光 \\ Karachi \\ Leadership and Ideas for Tomorrow}

Business Review

Volume 8 Issue 2 July-December 2013

7-1-2013

\title{
Explaining China's economic performance from the perspective of non-conventional determinants
}

Jingjing Yang

Hunan University, China

Sana Khalil

Hunan University, China

Follow this and additional works at: https://ir.iba.edu.pk/businessreview

Part of the International Economics Commons, and the Political Economy Commons

\section{c) (7)}

This work is licensed under a Creative Commons Attribution 4.0 International License.

\section{Recommended Citation}

Yang, J., \& Khalil, S. (2013). Explaining China's economic performance from the perspective of nonconventional determinants. Business Review, 8(2), 12-29. Retrieved from https://doi.org/10.54784/ $1990-6587.1283$

This article is brought to you by iRepository for open access under the Creative Commons Attribution 4.0 License and is available at https://ir.iba.edu.pk/businessreview/vol8/iss2/2. For more information, please contact irepository@iba.edu.pk. 


\title{
ARTICLE
}

\section{Explaining China's Economic Performance from the Perspective of Non-Conventional Determinants}

\author{
Jingjing Yang and Sana Khalil \\ Hunan University, China
}

\begin{abstract}
:
We analyze forecasts concerning China's growth slow-down and future prospects concerning its economic performance. Extending the discussion on China's possibility of going through a slow-down in future, we focus on the avoidance of such a possibility by drawing forth the role of gross capital formation, trade openness, higher education enrollment ratio, higher education expenditure, $R \& D$ expenditure, population growth and number of inventions in determining per capita income. These non-conventional determinants: number of inventions, government $R \& D$ expenditure, higher education enrollment ratio and higher education expenditure, show not only significantly positive link with per capita income but also exhibit strong explanatory power in determining per capita income. We apply several techniques (robust regression analysis, Driscoll and Kraay (1998) method, Fixed effects, Random effects estimations and Arellano-Bond GMM estimation) to analyze the sensitivity of our results which show that our variables of interest are robust to heteroscedasticity, autocorrelation of type $M A(q)$, and contemporaneous cross-sectional dependence.
\end{abstract}

Key words: Per capita Income, Growth Slow-down, Higher Education, R\&D Expenditure, Inventions

\section{JEL Codes: O1, O2, O3}

\section{Introduction}

\section{1- Background}

This paper provides an empirical investigation and analysis of forecasts concerning China's growth slow-down and standard of living (as generally depicted by per capita income). According to World Bank (2013) estimates, China's GDP growth rate would gradually decline from an average 8.5 percent in 2011-2015 to around 5 percent in 2026-2030. ${ }^{1}$ Labor growth (growth of labor force) and labor productivity growth will slow down from an average 0.3 and 8.3 percent respectively in 2011-2015 to -0.4 and 5.5 percent respectively in 2026-2030. Two factors are set to constrain China's current spree of rapid economic growth: first, the contribution from labor is set to decline due to lower expansion of its working-age population (which is estimated to

\footnotetext{
1 The data quoted in the paper, unless otherwise stated, comes from the World Bank and the Development Research Center of the State Council, P. R. China, 2013, China 2030: Building a Modern, Harmonious, and Creative Society, Washington, DC: World Bank.
} 
be eventually negative from 2015 onwards), second, total factor productivity growth which has been a source of China's past growth (Brandt and Zhu, 2010; Young, 2003) will decline significantly since much of the productivity gains due to reallocation from agriculture to industry have already been reaped. Much of the growth originating due to shifting and reallocation of resources from agriculture to industry has already been actualized and going further on from this point onwards continued capital accumulation will ineluctably generate less growth due to decreasing returns to capital and labor. Meanwhile, China is set to undergo major demographic transition whereby old age dependency ratio will more than double in upcoming two decades and the size of its labor force will shrink. Total factor productivity has also started declining as economy has already reaped the benefits from first-generation policy initiatives and gains from second-generation policy measures are more likely to have less impact on growth. Amid this whirlpool of transitions lie the challenges to support sustained economic growth that is inevitable for a leap toward higher-income level.

Future challenges apart, China's overall experience of sustained economic growth over past thirty years is unprecedented worth an exegesis. Justin Yifu Lin's recent book "Demystifying the Chinese Economy" provides a historical perspective in this regard. According to Lin (2011), before the advent of Industrial Revolution, China was still a leader in innovation as it enjoyed having the largest population in the world that endowed it with a huge stock of craftsmen and farmers. It can therefore be asserted, that even prior to the Industrial Revolution, China had a comparative advantage in terms of its unique endowments of human capital stock. The initial drivers of China's comparative advantage were its labor-intensive industries. However, with the advent of Industrial Revolution which marked the essentiality of capital-intensive industries, the need to shift from an agrarian economy to an industrial one turned dire. China's economic transition can be traced back to 1979 when a dual-system was adopted whereby protection and subsidies were granted to develop the capital-intensive industrial sector while liberalizing the labor-intensive sector by allowing private participation and foreign direct investment. This dualsystem of economic shift bore fruits in terms of dynamic economic progress and sustained growth.

Reaping the benefits of its economic initiatives taken in past, China today stands as the world's second largest economy and the largest exporter. In 2008, China's per capita income was reported to be around 21 percent of the United States. China's per capita income in 2008 matched the same level as the per capita income of Korea and Japan in 1977 and 1952 respectively (Lin, 2011). Apart from focusing on sustained economic growth, China's recent economic policies seem to be laying more emphasis on environmental and social objectives which are underscored in China's next Five-Year Plan for 2011-2015. China's 12 ${ }^{\text {th }}$ Five-Year Plan for 2011-2015 centers more attention to carrying out market-based structural reforms, narrowing the rural-urban differences, shifting the growth and development model from quantity-based to quality-based and stemming the growing income inequality.

In our paper, we provide an analysis of China's growth performance (whether growth has slackened or not) and gauge new derivers of per capita income. We use regional level data over 2003-2011 (the selection of years is based on availability of data and ensuring a sample with minimum missing values) to discuss economic development from the perspective of higher education, research and development and inventions. Our data comes from National Bureau of Statistics of China. In the next part we would discuss the historical trends in main macroeconomic fundamentals and comparative analysis with South Korea and Japan. Section two highlights whether middle income trap is a myth or reality and its implications for China's case, section three 
delves into China's growth slow-down and future growth prospects, section four propounds means to avoiding the middle income trap by analyzing the role of higher education, inventions and R\&D efforts in determining per capita income, section five propounds a basic framework for the analysis of the determinants of per capita income, section six and seven draw forth empirical estimations and conclusion respectively.

\subsection{Historical trends in main Macroeconomic fundamentals}

Before actually moving toward the discussion concerning China's future economic performance, it's necessary to peep through the historical trends in main Macroeconomic fundamentals. Graph ${ }^{2} 1$ shows the zigzag pattern of China's economic growth over past five decades. One undeniable aspect about China's growth is the incredible "resilience" of its economy in the face of slumps. Whether China can continue such remarkable display of resilience in future is still to be seen. Another aspect of China's growth is its sustained trade surplus which has been maintained since 1990s till present. Graph 2 reflects the export and import shares in GDP over 1980-2011. China has successfully maintained a positive current account since 2006. The gap between export and import shares in GDP widened in late 2000s but eventually started narrowing down over 2008-2011China has yet to see how this narrowed gap would effect its economic growth in future since the past economic growth was very much linked with its export growth. Savings and gross capital formation depict rising pattern (Graph 3) which does auger well for future growth. From the perspective of higher saving and gross capital formation, China stands as an outlier among other rapidly developing countries (Eichengreen, Park and Shin (2012). Thus, in forecasts for China's economic growth, higher savings and investment levels could be regarded as the forerunners of future growth. Comparing the industry value added and agricultural value added (Graph 4), major slump in the latter is quite obvious since China has capitalizing on its industrial growth while shifting resources from agriculture to industry (Lee and Hong, 2012). The gap between the two has widened tremendously over 1980-2011 whereby industrial value added shows stable rising pattern.

\subsection{China's R\&D, High-tech exports, Higher education and inventions: Comparison with Japan and South Korea}

The available figures from World Bank data on China's public spending on education as percentage of GDP (both current and capital) show that share of education expenditure in GDP by government was around 1.4 percent in 1971 to 1.9 in 1999 (data for next years is not available). Comparing that figure with those of Japan's, it's not surprising to note that the government has maintained a handsome figure over the years. Government educational spending as percent of GDP was 3.7 percent in 1971 which rose sharply to more than 5 percent over 1980s (the remarkable aspect is the sustained portion of education expenditure in GDP to more than 5 percentage over 1980-989) to decline later over 1990s to finally close at 3.7 percent in 2011 . This policy is quite congruent with that of Korea's over 1970-2011. In 1970, share of government education expenditure in GDP was around 3.45 percent which jumped up to 6.5 percent in 1982 and was declined during the later part of 1980s. However, as of 2000, the figures again jumped up and an average of 4 percent was maintained for 2000-2011, as of 2011 the figure reported was 5 percent.

\footnotetext{
${ }^{2}$ Data used for the graphs 1-4 and referred in the discussion here is extracted from World Bank
} database 
Gross enrollment ratio in higher education (as percentage of total population) for China was nearly 0.13 in 1970 and 7.95 in 2000 which increased manifolds in a short span of eleven years to close at 26.79 as of 2011. Comparing that with Korea's, the gross enrollment ratio in higher education was 7.25 in 1971 and 103.11 as of 2011. Japan's gross enrollment ratio in higher education was 17.6 in 1971 and 50.74 in 2010. The comparative figures imply that China still needs to focus more on higher education, $R \& D$ and inventions to catch up with its more developed counter parts.

R\&D expenditure (both public and private) as percentage of GDP for China more than tripled from 0.56 percent in 1996 to more than 1.7 percent in 2009. Comparing that figure with Korea and Japan's, their R\&D expenditure figures were around 2.42 and 2.7 percent respectively in 1996 which later rose to 3.73 and 3.3 percent respectively in 2010 .

Share of high-technology exports in total manufactured exports for China (hightechnology exports as percent of manufactured exports) was merely 6.4 percent in 1992 which skyrocketed over the years to clinch a gigantic proportion of more than 25 percent in 2011. Same increasing trend can be discerned in the share of exports related to information technology and communication which was around 17 percent in 2000, but significantly incremented over the years to stand at 29 percent in 2010.

Patent applications filed by Chinese residents through Patent Cooperation Treaty procedure were only 4,065 in 1985. This figure incremented sharply over the years and as of 2011 there were 415,829 (or 0.41 million) patent applications filed by Chinese residents.

The comparison of figures does suggest that Korea and Japan, in their initial and later phases of development, exhibited tremendous efforts in developing a strong human capital base of highly educated students while expediting R\&D and innovation efforts. However, whether such efforts are useful in avoiding a middle income trap requires further debate and research. In our paper, we would resort to finding associations between these socio-economic factors and per capita income in our effort to propound an empirical study pertaining to their role in the avoidance of middle income trap.

\section{Identifying growth slow-down}

China's growth rate decelerated to less than $8 \%$ in 2012 from a handsome figure of $10 \%$ in 2010. Speculations about continued slow-down of giant economy of China have already ripened in echelons of economists and policy makers.

Studies that focus on identifying the growth slow-down can easily be distinguished as two-pronged: those relying on statistical methods to chalk out growth slowdowns (Ben-David and Papell, 1998; Berg, Ostray and Zettlemeyer, 2012) and the others that apply rules of thumb to discern the growth slow-down ( Eichengreen, Park and Shin, 2012; Hausman, Rodriguez and Wagner, 2006; Aiyar et al, 2013). While the former notch of studies generally employ algorithm techniques, the most popular ones being Bai-perron (2003) and Harding and Pagan (2002) methods to identify growth minima and maxima, the latter stream of literature relies on laying down conditions for defining growth slowdowns and then meeting those conditions. A simple yet intuitive approach (Hausman, Pritchett and Rodrick, 2005; Eichengreen, Park, and Shin, 2012; Agenor, Canuto, and Jelenic, 2012) to applying this rule of thumb is to define a phase of growth slow-down as one which satisfies the following condition; 
i) $\quad \mathrm{gYt}, \mathrm{t}-\mathrm{n} \geq 3.5 \%$ per annum,

ii) $\mathrm{gYt}, \mathrm{t}-\mathrm{n}-\mathrm{gYt}, \mathrm{t}+\mathrm{n} \geq 2 \%$ per annum,

iii) iii) $\mathrm{Yt}>10,000$

where gYt, $\mathrm{t}-\mathrm{n}$ is the average growth of per capita income (measured in 2005 constant international purchasing power parity prices) between year $t$ and $t-n$, while $g Y t, t+n$ is the average growth rate between years $\mathrm{t}$ and $\mathrm{t}+\mathrm{n}$. The first condition stipulates that the average growth rate in $\mathrm{n}$ years should be greater than $3.5 \%$ per annum prior to a slow-down. The second condition requires at least $2 \%$ decline in the average growth rate of n-years. Finally, the third condition sets up a limit for per capita income to be more than 10, 000 thereby excluding poor and lower-middle countries from the analysis (since these countries experience serious economic difficulties hard enough to be accounted for in terms of growth slow-down due to natural heating-up of the economy).

Yet another intuitive approach that heavily draws upon growth theories and conditional convergence framework identifies the slack-periods in term of abrupt diversions from growth predictions (Aiyar et al, 2013). Using the conditional convergence framework (which predicts that rich countries grow slower than poor countries), this approach regresses growth rate of output per capita on lagged values of output per capita, physical and human capital stock to get predicted growth rates conditional upon the level of income and endowments of factors. It, then, defines the residuals as actual growth rates less estimated growth rates. That is;

$$
\text { rest - rest- } 1<\mathrm{p}(0.20)
$$

Where $\mathrm{p}(0.20)$ reflects the 20th percentile of the distribution of differences in the residuals from one period to another. Positive residuals would, then, imply that the country is experiencing faster growth while negative residuals would mean vice versa.

Using predicted values of growth rate and estimated growth rates (at regional level), we explore evidence of growth slow-down across regions over 2003-2011. The scatter plot in figure 1 largely reflects stability but exposes slumps in the tail. This pattern is in line with the actual data on growth rate of China's per capita GDP (World Bank Data) whereby growth picked up from $9.3 \%$ in 2003 to 13.6 in 2007 after which growth suffered from significant slumps to reach at $8.7 \%$ in 2011. Figure 1 reflects that at a regional level Chinese economy did exhibit a slump but some observations also reflect the upward pattern which may imply that some regions successfully avoided the slump. Thus it could be inferred from figure 1 that some of the regions did experience slowdown while others might not. The actual dataset on the growth rates of the regions (from China Statistical Yearbook) does provide a backup for such intuition. The regional level data indicates that Guizhou, Xingjiang, Sichuan, Henan, Beijing and Liaoning were some of the regions that showed a downward growth trend from 2003 to 2011 (China Statistical Database). On the other hand, Anhui, Hebei, Heilongjiang, Hunan, Jilin and Inner Mangolia were some of the regions that showed an upward growth trend. Figure 2 reflects the relation between growth and lagged growth over 2003-2011. It brings forward two distinctive patterns; a declining trend and an increasing trend. This can further signal toward the intuition that some regions experienced slowdown while others maintained growth acclivity.

Figure 3 tries to explore the link between per capita income and growth over 2003-2011 using the panel data from 31 regions. The figure shows the link between per capita income and growth is largely positive. This could have a number of implications concerning growth prospects and convergence: first, decreasing returns to capital and labor (as increasingly debated by future 
forecasts of China's growth) have not yet slowed down the growth of richer regions, second, the intuition that poor regions would grow faster than the rich ones is simply negated. The correlation between growth and per capita income turns out to be 0.73 which, rather, may imply that rich regions are experiencing higher growth by capitalizing on their high per capita income.

Having a look at the studies that predict slowdown for China, a general pessimism can easily be discerned. For example, Wilson and Stupnytska (2007) expect a future growth forecast of 5.8 percent over 2008-2030 for China. Using growth accounting framework, Lee and Hong (2012) base their growth projections on total factor productivity (TFP) growth estimated through growth derivers such as capital to labor ratio, saving rates, stock of patents, years of schooling, openness and demographic variables. They find that China appears as an outlier with an especially higher growth of capital to labor ratio. The authors, further on, project a growth rate of 6.1 to 7 percent for 2011-2020 and 5 to 6.2 percent for 2021-2030. The authors suggest a slower growth of growth derivers: labor force growth, growth in educational attainment, growth of capital stock and TFP growth. Slower growth is indicated to result from the convergence of capital to labor ratio, TFP to advanced-economic levels while slower growth of educational attainment is expected once enrollment ratios reach reasonably higher levels due to ageing population.

On the other hand, an optimistic forecast comes from Fogel (2007) who forecasts a growth of around 8.4 percent over 2001-2040 for China based on demographic trends and assumptions about investment in education.

Based upon myriads of forecasts about implications that a slowdown is coming for China in upcoming years, it becomes highly essential to explore determinants of per capita income that can help in avoidance of growth slow-down.

\section{Basic framework for the determinants of per capita income}

The basic framework for the estimation of per capita income can be derived from the augmented version (Mankiw, Romer and Weil, 1992) of the basic neoclassical growth model (Solow, 1956). Assuming a cobb-douglas production function, income, $\mathrm{Y}$, at time, $\mathrm{t}$, can be written as follows;

$$
\mathrm{Y}(\mathrm{t})=\mathrm{K}(\mathrm{t})^{\alpha} \mathrm{H}(\mathrm{t})^{\beta}(\mathrm{A}(\mathrm{t}) \mathrm{L}(\mathrm{t}))^{1-\alpha-\beta}
$$

Where $\mathrm{K}$ and $\mathrm{H}$ represent physical and human capital, $\mathrm{L}$ represents Labor and $\mathrm{A}$ stands for the level of technology. Over time, technology and labor grow exogenously at rates $g$ and $n$. solving for physical and human capital per unit of labor, the dynamics of growth can be summarized as follows;

$$
\begin{aligned}
& \dot{k}(\mathrm{t})=\mathrm{s}_{\mathrm{k}}(\mathrm{t}) A(\mathrm{t})^{1-\alpha-\beta} \mathrm{k}(\mathrm{t})^{\alpha} \mathrm{h}(\mathrm{t})^{\beta}-(\mathrm{n}(\mathrm{t})+\delta) \mathrm{k}(\mathrm{t}) \\
& \mathrm{h}^{\prime}(\mathrm{t})=\mathrm{s}_{\mathrm{h}}(\mathrm{t}) A(\mathrm{t})^{1-\alpha-\beta} \mathrm{k}(\mathrm{t})^{\alpha} \mathrm{h}(\mathrm{t})^{\beta}-(\mathrm{n}(\mathrm{t})+\delta) \mathrm{h}(\mathrm{t})
\end{aligned}
$$

Where $\mathrm{k}(\mathrm{k}=\mathrm{K} / \mathrm{L}$ and $\mathrm{h}=\mathrm{H} / \mathrm{L})$ and $\mathrm{h}$ represent growth rate of physical and human capital per unit of labor while $\mathrm{s}_{\mathrm{k}}, \mathrm{s}_{\mathrm{h}}$ and $\delta$ are rates of investment in physical and human capital and depreciation rate. Assuming $\alpha+\beta<1$ (decreasing returns to physical and human capital), the steady-state dynamics can be summarized as follows;

$$
\begin{aligned}
& \ln \mathrm{k}^{*}(\mathrm{t})=\ln \mathrm{A}+\frac{1-\beta}{1-\alpha-\beta} \ln \mathrm{s}_{\mathrm{k}}(\mathrm{t})+\frac{\beta}{1-\alpha-\beta}+\operatorname{lns}_{\mathrm{h}}(\mathrm{t})-\frac{1}{1-\alpha-\beta} \ln (\mathrm{n}(\mathrm{t})+\mathrm{g}+\delta) \\
& \ln \mathrm{h}^{*}(\mathrm{t})=\ln \mathrm{A}+\frac{\alpha}{1-\alpha-\beta} \ln \mathrm{s}_{\mathrm{k}}(\mathrm{t})+\frac{1-\alpha}{1-\alpha-\beta}+\ln _{\mathrm{h}}(\mathrm{t})-\frac{1}{1-\alpha-\beta} \ln (\mathrm{n}(\mathrm{t})+\mathrm{g}+\delta)
\end{aligned}
$$




$$
\ln \mathrm{y}^{*}(\mathrm{t})=\ln \mathrm{A}+\frac{\alpha}{1-\alpha}\left(\operatorname{lns}_{\mathrm{k}}(\mathrm{t})-\ln (\mathrm{n}(\mathrm{t})+\mathrm{g}+\delta)+\frac{\beta}{1-\alpha} \ln \mathrm{h}^{*}(\mathrm{t})\right.
$$

Where per capita income, $y=Y / L$ and $\ln$ stands for log-linearization.

Since the steady-state level of human capital in the last equation is unobservable, a log linearized form can be stated as follows;

$\ln h^{*}(\mathrm{t})=\ln \mathrm{h}(\mathrm{t})+\rho \cdot \Delta \ln \mathrm{h}(\mathrm{t})$

Where $\rho$ is a function of technological parameters $(\alpha, \beta)$.

Finally, the steady-state income can be given as follows;

$$
\ln \mathrm{y}^{*}(\mathrm{t})=\frac{\alpha}{1-\alpha} \ln \mathrm{s}_{\mathrm{k}}(\mathrm{t})-\frac{\alpha}{1-\alpha} \ln (\mathrm{n}(\mathrm{t})+\mathrm{g}+\delta)+\frac{\beta}{1-\alpha} \ln \mathrm{h}(\mathrm{t})+\frac{\beta}{1-\alpha} \rho \cdot \Delta \ln \mathrm{h}(\mathrm{t})+\ln \mathrm{A}(0)+\mathrm{gt}
$$

Eq. (1) reflects that the long-run steady-state level of per capita income can be determined by investment rates of physical and human capital $\left(s_{k}\right.$ and $s_{h}$ ), growth rate of population, $\mathrm{n}$, and the level of technology. This long-run steady-state equilibrium relationship can be estimated directly either in its level form or through growth-based form. The model has generally been more often used in its growth-based form to examine convergence and to compare growth specifications in different countries. On the other hand, estimation of the long-run steadystate relation in static form has been employed by a handful of studies (Hall and Jones, 1999; Bernake and Gurkaynak, 2001). However, the static or dynamic specifications are considered to yield congruent results (Hervé Boulhol, Alain de Serres and Margit Molnar, 2008) for homogenous countries (which are not far from their steady states and share similar characteristics).

\section{Empirical results and discussion}

In order to analyze the full specification, we estimate following regression equation;

$$
\begin{gathered}
\ln Y i t=\alpha+\beta 1 \text { GCAit }+\beta 2 \text { Opennessit }+\beta 3 \text { PERit }+\beta 4 \text { SERit }+\beta 5 \text { HERit }+\beta 6 \text { R\&Dit }+\beta 7 \\
\text { Inventionsit }+\beta 8 \text { EduExpit }+\beta 9 \text { PopGrowthit }+ \text { cit }+ \text { dit }+ \text { cit }
\end{gathered}
$$

$$
\mathrm{i}=1, \ldots . .31 ; \quad \mathrm{t}=2003, \ldots .2011
$$

where $\mathrm{Y}_{\text {it }}$ is per capita income (calculated as gross regional output divided by total population for region $i$ at time $t), \mathrm{GCA}_{i t}$ is the ratio of gross capital formation to gross regional output (used as a proxy for investment to GDP ratio), openness it $_{\text {it }}$ is a proxy for trade liberalization and is measured by sum of total exports and imports divided by gross regional output, $\mathrm{PER}_{\mathrm{it}}, \mathrm{SER}_{\mathrm{it}}$ and $\mathrm{HER}_{\mathrm{it}}$ are the primary enrollment ratio, secondary and higher education enrollment ratios respectively. $R \& D_{\text {it }}$ is per capita government expenditure on $R \& D$ activities at institutions of higher education (R\&D expenditure divided by total population), Inventions $s_{i t}$ is the number of inventions made (proxied by number of patents granted), EDUEXP $\mathrm{E}_{\text {it }}$ is government appropriation of funds per student at higher education institutions, PopGrowth ${ }_{i t}$ is the population growth rate, $\mathrm{c}_{\mathrm{it}}$ a and $\mathrm{d}_{\mathrm{it}}$ are dummies for controlling region effects and time effects while $\varepsilon_{\mathrm{it}}$ is an error term.

Our aim is to study the roles played by inventions, stock of highly educated students, R\&D efforts and government appropriation of funds for higher education per each student at higher educational level in determining per capita income. Measures such as R\&D efforts, patents and highly educated personnel are associated with "national technological efforts" (Lall, 1992). 
Measuring technological efforts of a country empirically is a difficult exercise therefore studies resort to proxies to remedy that. A few studies forward suggestions for measuring a country's innovative capacity or technological efforts through number of patents. Furman and Hayes (2004), for example, use number of patents to measure the innovative capacity of countries and find large variations in inventions across countries at similar income levels suggesting that the link between patents and income could be different across different countries.

Our dataset comprises of panel data from 31 regions of China over 2003-2011 available from National Bureau of Statistics of China. ${ }^{3}$

In table 1 we regress per capita income on the set of explanatory variables conventionally associated with per capita income i.e. physical capital, human capital (measured by primary and secondary enrollment ratios), trade and population growth. Results in table 1 indicate that higher education enrollment ratio and trade openness stand as the strongest variables among others in their individually positive influence over per capita income accounting for $63 \%$ and $43 \%$ of the variance in per capita income respectively. Contribution of capital formation turns out to be positively but insignificantly related to per capita income. Population growth shows a negative and significant relation with per capita income. The noticeable aspect in the above table is that the primary and secondary enrollment ratios turn out to be negatively related to per capita income. An intuition behind this could be that the stock of students at primary and secondary educational level represents "idle human capital" which is not involved in the production function directly. On the other hand higher education is usually the last stage of education more closely associated with production function in its spill-over effects. Therefore, stock of students at higher education level would represent "highly educated human capital" closely linked with the economic output. The negative link between primary and secondary enrollment ratios with per capita income can imply that regions with higher enrollment ratios at primary and secondary levels are those which have lower per capita income. That is, poor regions have higher ratios of primary and secondary enrollment. Also, the positive link between higher education and per capita income could suggest that regions with higher enrollment ratio for higher education are those which have higher per capita income or that the rich regions are experiencing higher enrollment ratio for higher education.

Table 2 explores the explanatory powers of variables of interest when other variables are held constant. Results indicate that income per person is significantly and positively related with the four variables of interest. The adjusted $\mathrm{R}^{2}$ is 0.89 indicating that around 89 percent of the variation in income per person can be explained by the four variables. Table 2 indicates a one percent increase in higher education enrollment ratio increases income per person by 0.78 percent. Further on, higher per capita income is positively linked with higher appropriation of funds for higher education; a one percent change in higher education expenditure per student raises the income per person by 0.57 percent. Higher education enrollment rate and expenditure is crucial as a highly educated labor force can imitate technology faster (Nelson and Phelps, 1996) and contribute more to labor productivity. Also, higher education can be more closely linked with the production function since it is usually the last educational stage after which students join the labor

\footnotetext{
${ }^{3}$ The link to the data can be accessed from http://www.stats.gov.cn/english/statisticaldata/yearlydata/
} 
force as highly skilled workers. From this perspective, higher education can be considered more important than primary and secondary education.

R\&D expenditure per person is substantially positively related with per capita income. A one percent increase in $R \& D$ expenditure per person leads to 0.08 percent increase in per capita income. The result signals toward the fact that higher "technological efforts" contribute positively toward per capita income (Lall, 1992).

The results in table 2 also indicate a statistically significant positive relationship between inventions and income per person. A one percent increase in number of inventions increases income per person by 0.1 percent. This finding is in line with the findings by Fagerberg and Srholec (2008) who found a close correlation between economic development (as measured by GDP per capita) and "innovation system variable". Using factor analysis on data from 115 countries over 1992-2004, Fagerberg and Srholec (2008) found that four principal factors jointly explained about 75 percent of the variance of the total set of indicators. These four principal factors (along with electricity consumption and education, are jointly termed as "innovation system variable") were associated with "technological capability" and were measured through patenting, ICT infrastructure, scientific publications, and ISO 9000 certifications.

Table 3 shows the regression results under full model. Estimated coefficients of the selected variables remain significant and positively related to income per person: HER 0.71(.062), R\&D expenditure per person $0.062(.036)$, number of patents granted $0.106(0.015)$ and Education expenditure per student $0.443(0.041)$ are almost comparable with the coefficients in table 1 .

Gross capital formation ratio (as measured by share of fixed capital formation in GDP) and trade openness (as measured by sum of the total exports and imports divided by gross regional output) are positively related to income per person which is congruent with the conventional concepts about physical capital investment, trade openness and output. Ratio of gross fixed capital formation to GDP (or share of fixed investment in GDP), which serves as a measure for investment in physical capital, is found to be positively associated with economic growth (Barro,1991; De Long and Summers ,1992). However, in our study we link investment in physical capital with per capita income and find that higher level of physical capital investment ratio raises standard of living. Also, the positive link between trade openness and per capita income is in line with the results found by Frankel and Romer (1999) who used cross country regression estimates to suggest that trade has a quantitatively large, robust yet moderately statistically significant, positive effect on per capita income. In their direct specification to estimate per capita income with population, area and trade share as the only dependent variables, they found that increasing the ratio of trade to GDP by one percentage point, per capita income is raised by around one-half and two percent. They also found that increasing both population and area by one percent, per capita income is raised by 0.1 percent.

\subsection{Comparative estimations: Robust regression, Driscoll and Kraay method, Fixed Effects and Random Effects}

Table 4 explores the links by comparing results under robust regression, fixed effects and random effects. Coefficients of the selected variables are congruent to those estimated under simple OLS in table 2. Column 2 and 3 of table 4 provide estimation results of the full model under Driscoll and Kraay (1998) method, fixed effects and random effects. 
Since we use a micro panel in which $\mathrm{T}<\mathrm{N}$, the data is likely to exhibit temporal and cross-sectional dependencies (Cameron and Trivedi, 2005, P.702). Also, ignoring the correlation of the disturbance terms over time and between entities can lead to biased estimation results. Therefore, in order to ensure validity of the results, panel data is used to adjust the standard errors of the coefficients for possible dependencies in the residual terms. According to Petersen (2009), while most of empirical studies employ regression methods that produce standard errors being robust to heteroscedasticity and autocorrelation, cross-sectional dependence across panels is widely left ignored. Provided that the disturbance term (or the unobservable factors) is uncorrelated with the independent variables, the coefficients under standard panel estimators would still be consistent but inefficient. However, standard error (SE) estimates under commonly applied techniques for covariance matrix estimation can be biased leading to invalid statistical inferences based biased standard errors (Driscoll and Kraay, 1998). Driscoll and Kraay method produces standard errors that are robust to general forms of temporal and spatial dependence, heteroscedasticity and autocorrelation. Although standard errors under Driscoll and Kraay method tend to be a bit optimistic, their sample properties (especially for micro panels) are significantly better than other techniques when cross-sectional dependence is present.

In the regression model with Driscoll and Kraay, standard errors are robust to disturbances being cross-sectionally dependent, auto correlated with type MA(q) and heteroscedasticity. With maximum lag of 2 with pooled OLS, column 2 of table 4 shows regression results with Driscoll and Kraay standard errors. Sensitivity of the coefficient estimates appears robust to heteroscedasticity, autocorrelation and cross-sectional dependence as the estimates how little change in comparison with estimates under robust regression. Coefficients for R\&D expenditure and population growth turn out to be insignificant under Driscoll and Kraay while other coefficients remain significant under $1 \%, 5 \%$ and $10 \%$ significance levels.

The fixed effects model is employed to control for all time-invariant differences between the regions, therefore the estimated coefficients under fixed effects model cannot be biased due to time-invariant characteristics (such as differences in demography, geography etc.) which are omitted from our analysis. However, the random effects model, unlike the fixed effects model, assumes the variations across the regions to be random (uncorrelated with the explanatory variables). Since the variations across the regions are expected to influence the dependent variable (income per person), random effects model could account for such variations. In order to verify such limitations, we diagnose both models by using Hausman test (to decide between fixed and random effects models) and Breush-Pagan Lagrange multiplier (LM) test (to decide between random effects and simple OLS model). The results reveal that when robust standard errors are not used, the Hausman test (to decide between fixed and random model) rejects the null hypothesis that differences in coefficients are not systematic and suggests that random effects model serves better.

Further on, diagnosing the random effects model (under robust standard errors), we test for Breusch-Pagan Lagrange multiplier (LM test). The LM test fails to reject the null hypothesis that there is no significant difference across regions thus suggesting that random effects would work better than simple OLS.

Results obtained through different estimation techniques in table1, 2, 3 and 4 indicate that our variables of interest: number of inventions, government R\&D expenditure, higher education enrollment ratio and higher education expenditure generally depict a significantly robust link with 
per capita income. However, other explanatory variables such as gross capital formation ratio, trade openness and population growth do reflect considerable sensitivity under different estimation methods and controls. The sensitivity of gross capital formation ratio (ratio of physical capital investment to GDP), population growth and trade openness under different controls and estimation methods is discussed in detail by Levine and Renelt (1992) and is beyond the context of this paper.

\subsection{Dynamic Panel Data Analysis under Arellano Bond GMM Estimation}

Dynamic panel data can be used to investigate the causal relationship between the dependent variable and explanatory variables. We use lagged values of the dependent variable as instrument in our dynamic panel data estimation under Arellano-Bond GMM method.

Results in colum1 of table 5 indicate that, holding other variables constant, higher education enrollment ratio, R\&D expenditure per person, Higher education expenditure per student, and numbers of inventions are substantially positively related to subsequent per capita income. The estimated coefficient for higher education enrollment ratio is 0.326 which means that a one percent increase in higher education enrollment ratio results in 0.32 percent increase in subsequent income per person. The estimated coefficient for higher education expenditure per student and R\&D expenditure per person are 0.089 and 0.117 which are both significantly positively associated with per capita income. Contribution of inventions toward per capita income turns out to be 0.077 percent. Based upon the results in colum 1 of table 5 , higher education enrollment ratio carries the strongest explanatory power in determining the subsequent standard of living which is quite plausible given the role played by higher education in improving productivity and overall quality of life. Column 2 and 3 indicate that the results remain significant when other variables are included with little change in estimated coefficients.

Column 4 and 5 replace $R \& D$ expenditure per person with $R \& D$ ratio (share of $R \& D$ expenditure in GDP) to test the strength of relationship between R\&D expenditure and standard of living. The results indicate that R\&D ratio is substantially positively related with subsequent income per person and the replacement of $R \& D$ per person with $R \& D$ ratio casts little or no significant change in estimated coefficients of other variables.

\section{Conclusion}

Extending the discussion on forecasts pertinent to China's future growth slow-down, our paper highlights the aspects concerning the avoidance of such possibility by drawing forth the analysis of determinants of per capita income.

Analyzing the prospects of growth slow-down for Chinese economy, we find that during 2003-2011 Chinese economy, as a whole, did exhibit a slump but at regional level some observations also reflect an upward pattern suggesting that some regions successfully avoided the slump. An intuition for such pattern could be that some of the regions experienced slowdown during this period while others may not. The real data available from China Statistical Database from National Bureau of Statistics of China does bolster such intuitions that some regions experienced growth slowdown while others continued growth acclivity.

Further on, we test the role of higher education enrollment ratio, government appropriation of funds per enrolled student at higher education institutions, government R\&D expenditure at public institutions and number of inventions (patents granted) in determining the 
standard of living. We use regional level data from 31 regions over 2003-2011 to bring forward empirical findings that link per capita income with gross capital formation, openness, higher education enrollment ratio, higher education expenditure, $R \& D$ expenditure, population growth and number of inventions made during that period. The empirical findings suggest that lower per capita income is associated with higher ratios of primary and secondary enrollment while higher per capita income is associated with higher ratio of higher education enrollment. Per capita income is positively associated with number of inventions made, government R\&D expenditure and higher education expenditure. Also, ratio of gross capital formation to gross regional product (which is treated as a measure of investment to GDP ratio) turn out to be positively related with per capita income in dynamic panel data estimations suggesting that higher investment to GDP ratio substantially raises the subsequent income per person. Results obtained through ArellanoBond GMM estimation suggest that a one percent increase in higher education enrollment ratio raises subsequent per capita income by 0.326 percent. Also, a one percent increase in higher education expenditure per students raise subsequent per capita income by 0.089 percent. Using share of $R \& D$ expenditure and $R \& D$ expenditure per person alternatively, the results suggest that per capita income is raised by 0.091 and 0.117 percent respectively. Estimated coefficient for inventions (number of patents granted) show that a one percent increase in number of inventions raises subsequent income per person by 0.07 percent.

Our results obtained using robust regression analysis, Driscoll and Kraay method, Fixed effects Random effects estimations and Arellano-Bond GMM estimation method help in analyzing the sensitivity of the estimated coefficients under different control and estimation techniques. We find that the results for our variables of interest are mostly robust to heteroscedasticity, autocorrelation of type $\mathrm{MA}(\mathrm{q})$, and contemporaneous cross-sectional dependence. However, other explanatory variables such as gross capital formation ratio, trade openness and population growth do reflect considerable sensitivity under different estimation methods and controls.

In conclusion, our analysis lays emphasis on higher education, $R \& D$ expenditure and invention efforts based upon their tremendous contribution toward per capita income. We propose that higher education, $R \& D$ and invention efforts can serve as a means to avoiding future growth slow-down for China.

\section{Acknowledgement}

We forward our gratitude to Dr. Ming He, Dr. Qu Dan of Hunan University, China; Professor Yingqi Wei of The York University, UK for their useful comments on earlier versions of the paper. The authors are grateful to acknowledge the support from sponsorships provided by The 2012 National Natural Science Foundation (71240026), The 2011 Natural Science Foundation of Hunan Province (11JJ5046) and The 2011 Social Science Foundation project in Hunan Province (11YBB080).

\section{References}

Agénor ,Pierre-Richard, Canuto, Otaviano, and Jelenic, Michael (2012) Avoiding Middle-Income Growth Traps. World Bank-Economic Premise. 98. Available from http://ideas.repec.org/s/wbk/prmecp.html. Viewed on March, 2013.

Bernake, B.S. and Gurkaynak, R.S. (2001) Is Growth Exogenous? Taking Mankiw, Romer and Weil Seriously. NBER Working Paper No. 8365. National Beaureu of Economic Research. 
Brandt, Loren and Zhu, Xiaodong (2010) Accounting for China's Growth. IZA discussion paper No. 4764.

Cameron, A. C., and Trivedi, P.K. (2005) Microeconometrics: Methods and Applications.

Cambridge University Press.

Canuto, Otaviano. 2011. Navigating the Road to Riches.(online) available from: www.projectsyndicate.org. (Accessed: March, 2013).

De Long, J. Bradford, and Lawrence Summers (1992) Equipment, Investment and Economic Growth: How Strong is the Nexus? Brookings Papers on EconomicActivity. P. 157-211.

Driscoll, J. C., and Kraay, A.C. (1998) Consistent Covariance Matrix Estimation with Spatially Dependent Panel Data. Review of Economics and Statistics. 80. P. 549-560.

Eichengreen, Barry, Donghyun Park and Kwanho Shin (2013). Growth Slowdowns Redux: New Evidence on the Middle-Income Trap. NBER Working Paper 1867. National Bureau of Economic Research.

Fagerberg, J. and Srholec, M. (2008) National Innovation Systems, Capabilities and Economic Development. Research Policy. 37. P. 1417-1435.

Fogel, R. (2007) Capitalism and Democracy in 2040: Forecasts and Speculations. NBER Working Paper No.13184. National Bureau of Economic Research, Massachusetts.

Jeffrey A. Frankel and David Romer (1999) Does Trade Cause Growth? The American Economic Review. 89 (3). P. 379-399.

Furman, J. L. and Hayes, R. (2004) Catching up or standing still? National innovative productivity among 'follower' countries. Research Policy. 33. P. 1329-1354.

Hall, R.E. and Jones, C.I. (1999) Why Do Some Countries Produce so Much More Output per Worker Than Others?. Quarterly Journal of Economics. 114 (1).

Hervé Boulhol, Alain de Serres and Margit Molnar. (2008) The contribution of Economic Geography to GDP per Capita. OECD Journal: Economic Studies. 1. P. 1-37.

Justin Yifu Lin (2011) Demystifying the Chinese Economy. Cambridge University Press. P.150179

Lall, S. (1992) Technological capabilities and industrialization, World Development. 20. P. 165186.

Lee, J-W., and Hong, K. (2012) Economic Growth in Asia: Determinants and Prospects. Japan and the World Economy. 24 (2). P. 101-113.

Levine, Ross and Renelt, David (1992) A Sensitivity Analysis of Cross-Country Growth Regressions. The American Economic Review. 82(4). P.942-963.

Mankiw, N. G., D. Romer and D. N. Weil (1992) A contribution to the empirics of economic growth. Quarterly Journal of Economics. 107 (May). P. 407-437.

Petersen, M.A (2009) Estimating Standard Errors in Finance Panel Data Sets: Comparing Approaches. Review of Financial Studies. 22(1). 
Solow, R. M. (1956) A Contribution to the Theory of Economic Growth. Quarterly Journal of Economics. 70. P. 65-94.

Young, Alwyn (2003) From Gold to Base Metals: Productivity Growth in the People's Republic of China during the Reform Era. Journal of Political Economy. P. 1120-1161.

Wilson, D., and Stupnytska,A. (2007) The N-11: More Than an Acronym. Global Economics Paper No. 153. Goldman Sachs, New York.

World Bank and the Development Research Center of the State Council, P. R. China. (2013). China 2030: Building a Modern, Harmonious, and Creative Society. Washington, DC: World Bank. DOI: 10.1596/978-0-8213-9545-5. License: Creative Commons Attribution CC BY 3.0.

\section{Appendix:}

Table 1: Determinants of per capita income: Physical capital, Human capital, Trade and population growth (Independent variable $=$ Log Per capita income)

\begin{tabular}{|c|c|c|c|c|c|c|c|c|}
\hline $\begin{array}{l}\text { Independent } \\
\text { Variables }\end{array}$ & (1) & (2) & (3) & (4) & (5) & (6) & (7) & (8) \\
\hline GCA & $\begin{array}{l}.182 \\
(.177)\end{array}$ & & & & & & $\begin{array}{l}.863 \\
(.108)^{*}\end{array}$ & $.513(.093)^{*}$ \\
\hline Openness & & $\begin{array}{l}.447 \\
(.03)^{*}\end{array}$ & & & & & $\begin{array}{l}.387 \\
(.026)^{*}\end{array}$ & $.26(.024)^{*}$ \\
\hline PopGrowth & & & $\begin{array}{l}-.094 \\
(.012)^{*}\end{array}$ & & & & $\begin{array}{l}-.0222 \\
(.012)^{* * * *}\end{array}$ & $\begin{array}{l}.0288 \\
(.010)^{* *}\end{array}$ \\
\hline PER & & & & $\begin{array}{l}-1.007 \\
(.081)^{*}\end{array}$ & & & $\begin{array}{l}-.490 \\
(.093)^{*}\end{array}$ & $\begin{array}{c}-.339 \\
(.077)^{*}\end{array}$ \\
\hline SER & & & & & $\begin{array}{l}-0.548 \\
(.081)^{*}\end{array}$ & & $\begin{array}{l}-.282) \\
(.052)^{*}\end{array}$ & $-.165(.044)^{*}$ \\
\hline HER & & & & & & $\begin{array}{l}1.126 \\
(.05)^{*}\end{array}$ & & $.73(.062)^{*}$ \\
\hline Adj. R & .0002 & 0.43 & 0.17 & 0.35 & 0.14 & 0.63 & 0.68 & 0.78 \\
\hline No.of Obs. & 279 & 279 & 279 & 279 & 279 & & 279 & 279 \\
\hline
\end{tabular}

Note: Table 1 shows OLS regression results for the component specification. Standard errors are given in parenthesis and are robust to heteroscedasticity. ${ }^{*}$ Shows significance at $1 \%$ level; ** at $5 \% ; * * *$ at $10 \%$.

Data source: The link to the data used in all the regressions can be accessed from http://www.stats.gov.cn/english/statisticaldata/yearlydata/

Table 2: Determinants of per capita income: Higher education, R\&D and inventions (Independent variable $=$ Per capita income)

\begin{tabular}{|c|c|c|c|c|c|c|c|}
\hline & OLS & OLS & OLS & OLS & OLS & $\mathrm{RE}$ & $\mathrm{FE}^{1}$ \\
\hline HER & $\begin{array}{l}1.126 \\
(.05)^{*}\end{array}$ & & & & $\begin{array}{l}0.787 \\
(0.061)^{*}\end{array}$ & $\begin{array}{l}.6525793 \\
.098)^{*}\end{array}$ & $\begin{array}{l}.5853891 \\
.1414)^{*}\end{array}$ \\
\hline EduExp & & $\begin{array}{l}.368 \\
(.072)^{*}\end{array}$ & & & $\begin{array}{l}0.537 \\
(0.032)^{*}\end{array}$ & $\begin{array}{l}.417366 \\
.0404) *\end{array}$ & $\begin{array}{l}.3277923 \\
.0930 *\end{array}$ \\
\hline$R \& D$ & & & $\begin{array}{l}.471 \\
(.015)^{*}\end{array}$ & & $\begin{array}{l}0.089 \\
(0.035) * *\end{array}$ & $\begin{array}{l}.2376657 \\
.058)^{*}\end{array}$ & $\begin{array}{l}.2968708 \\
.079)^{*}\end{array}$ \\
\hline Inventions & & & & $\begin{array}{l}.259 \\
(.017)^{*}\end{array}$ & $\begin{array}{l}0.109 \\
(0.016)^{*}\end{array}$ & $\begin{array}{l}.0587835 \\
.0350)^{* * *}\end{array}$ & $\begin{array}{l}.0678063 \\
(.050)\end{array}$ \\
\hline Adj. $R^{2}$ & 0.63 & 0.081 & .77 & 0.43 & 0.89 & 0.95 & 0.95 \\
\hline No. of Obs. & 279 & 279 & 279 & 279 & 279 & 279 & 279 \\
\hline
\end{tabular}


Note: Standard errors are in parenthesis and are robust to heteroscedasticity. *: Shows significance at $1 \%$ level; $* *$ at $5 \%$ level; $* * *$ at $10 \%$ level.

Table 3: Estimation under Full Model: Dependent variable= Income per person

\begin{tabular}{|l|l|l|l|}
\hline & $(1)$ & $(2)$ & $(3)$ \\
\hline GCA & $1.034(.121)^{*}$ & $.513(.10)^{*}$ & $.220(.068)^{*}$ \\
\hline Openness & $.460(.028)^{*}$ & $.260(.024)^{*}$ & $.104(.016)^{*}$ \\
\hline PER & & $-.339(.074)^{*}$ & $-.078(.055)$ \\
SER & & $-.165(.041)^{*}$ & $-.054(.033)$ \\
HER & & $.730(.059)^{*}$ & $.711(.062)^{*}$ \\
\hline R\&D & & & $.062(.036)^{* *}$ \\
\hline Inventions & & & $.106(.015)^{*}$ \\
\hline EduExp & & & $.443(.041)^{*}$ \\
\hline PopGrowth & $-.0660(.009)^{*}$ & $.028(.009)^{*}$ & $.0105(.006)^{* * *}$ \\
\hline Adj. $\mathrm{R}^{2}$ & 0.59 & .79 & .91 \\
\hline Prob > F & 0.00 & 0.00 & 0.00 \\
\hline No. of Observations & 279 & 279 & 279 \\
\hline
\end{tabular}

Note: Table 3 shows OLS regression results for the full specification. Standard errors are in parenthesis and are robust to heteroscedasticity. *: Shows significance at $1 \%$ level; ** at $5 \%$; *** at $10 \%$ level.

Table 4: OLS (robust regression), OLS with Driscoll and Kray, FE and RE comparison

\begin{tabular}{|c|c|c|c|c|}
\hline & $\begin{array}{l}\text { OLS (Robust } \\
\text { regression) }\end{array}$ & $\begin{array}{l}\text { Pooled OLS with Driscoll and } \\
\text { Kraay std.err. }\end{array}$ & FE & $\mathrm{RE}$ \\
\hline GCA & $\begin{array}{l}.209 \\
(.061)^{*}\end{array}$ & $.2202 .108)^{* * *}$ & $\begin{array}{c}.1991 \\
(.132)^{* *}\end{array}$ & $-.182(.053)^{*}$ \\
\hline Openness & $.128(.014)^{*}$ & $\begin{array}{c}.104 \\
.018)^{*}\end{array}$ & $-.088(.025)^{* *}$ & $-.047 \quad(.022)^{* *}$ \\
\hline PER & $-.051(.043)$ & $\begin{array}{ll}.078 & (.049)\end{array}$ & $-.148 \quad(.080)^{* * *}$ & $-.116(.067)^{* * *}$ \\
\hline SER & $-.037(.024)$ & $-.054(.023)^{* * *}$ & $-.079(.017)^{*}$ & $-.078(.016)^{*}$ \\
\hline HER & $.709(.052)^{*}$ & $.7116(.135)^{* *}$ & $.707 .(065)^{*}$ & $.688 \quad .057)^{*}$ \\
\hline$R \& D$ & $.086(.027)^{*}$ & $.0620768 \quad(.096)$ & $.209(.040)^{*}$ & $.20 \quad(.034)^{*}$ \\
\hline Inventions & $\begin{array}{l}.100 \\
(.011)^{*}\end{array}$ & $.1065895 \quad(.029)^{* *}$ & $.042(.022)^{* *}$ & $.061(.018)^{* * *}$ \\
\hline EduExp & $\begin{array}{l}.383 \\
(.030)^{*}\end{array}$ & $.443 \quad(.062)^{*}$ & $.473(.052)^{*}$ & $.462(.036)^{*}$ \\
\hline PopGrowth & $\begin{array}{l}.016 \\
(.006)^{*}\end{array}$ & $.0105 \quad(.006)$ & $.028(.009)^{* *}$ & $.024 \quad(.007)^{* *}$ \\
\hline $\mathrm{R}^{2}$ & & 0.91 & 0.96 & 0.96 \\
\hline No. of Obs. & 279 & 279 & 279 & 279 \\
\hline
\end{tabular}

(fe) F test that all $u_{-} i=0: \quad F(30,239)=34.91 \quad$ Prob $>F=0.0000$ 
Note: Standard errors are in parenthesis and are robust to heteroscedasticity. *: Shows significance at $1 \%$ level; ** at $5 \% ; * * *$ at $10 \%$ level. In column 2, standard errors are based on Driscoll and Kraay (1998).

Table 5: Dynamic Panel Data Analysis under Arellano-Bond GMM Estimation

\begin{tabular}{|c|c|c|c|c|c|c|}
\hline 8 & (1) & (2) & (3) & (4) & (5) & (6) \\
\hline Ln GCA & & $\begin{array}{l}.098 \\
(.053)^{* * *}\end{array}$ & $\begin{array}{l}.101 \\
.0539)^{* *}\end{array}$ & $\begin{array}{l}.112 \\
(.053)^{* *}\end{array}$ & $\begin{array}{l}.106 \\
(.051)^{* *}\end{array}$ & $\begin{array}{l}.098 \\
(.052)^{* * *}\end{array}$ \\
\hline Ln Openness & & $\begin{array}{l}.022 \\
(.019)\end{array}$ & $\begin{array}{l}.022 \\
(.019)\end{array}$ & $\begin{array}{l}.019 \\
(.0190\end{array}$ & $\begin{array}{l}.02 \\
(.0189)\end{array}$ & $\begin{array}{l}.022 \\
(.018)\end{array}$ \\
\hline Ln PopGrowth & & & $\begin{array}{l}-.0015 \\
(.008)\end{array}$ & $\begin{array}{l}-.002 \\
(.008)\end{array}$ & & \\
\hline Ln PER & & & & & $\begin{array}{l}-.196 \\
(.074)^{* *}\end{array}$ & $\begin{array}{l}-.20 \\
(.073)^{* *}\end{array}$ \\
\hline Ln SER & & & & & $\begin{array}{l}.280 \\
(.069)^{*}\end{array}$ & $\begin{array}{l}.297 \\
(.068)^{*}\end{array}$ \\
\hline Ln HER & $\begin{array}{l}.326 \\
(.059) *\end{array}$ & $\begin{array}{l}.274 \\
(.068) *\end{array}$ & $\begin{array}{l}.263 \\
(.082)^{* *}\end{array}$ & $\begin{array}{l}.232 \\
(.085)^{* *}\end{array}$ & & \\
\hline Ln EduExp & $\begin{array}{l}.089 \\
(.032)^{* *}\end{array}$ & $\begin{array}{l}.065 \\
(.037) * *\end{array}$ & $\begin{array}{l}.060 \\
(.044)\end{array}$ & & $\begin{array}{l}.067 \\
(.037)^{* * *}\end{array}$ & $\begin{array}{l}.069 \\
(.037)^{* * *}\end{array}$ \\
\hline Ln R\&D ratio & & & & $\begin{array}{l}.091 \\
(.036)^{* *}\end{array}$ & $\begin{array}{l}.073 \\
(.034)^{* *}\end{array}$ & \\
\hline Ln R\&D & $\begin{array}{l}.117 \\
(.037)^{* *}\end{array}$ & $\begin{array}{l}.107 \\
(.037)^{* *}\end{array}$ & $\begin{array}{l}.107 \\
(.038)^{* *}\end{array}$ & & & $\begin{array}{l}.094 \\
(.037)^{* *}\end{array}$ \\
\hline Ln Inventions & $\begin{array}{l}.077 \\
(.021)^{*}\end{array}$ & $\begin{array}{l}.077 \\
(.021)^{*}\end{array}$ & $\begin{array}{l}.076 \\
(.021)^{*}\end{array}$ & $\begin{array}{l}.071 \\
(.022)^{* *}\end{array}$ & $\begin{array}{l}.075 \\
(.021)^{* *}\end{array}$ & $\begin{array}{l}.077 \\
(.021)^{*}\end{array}$ \\
\hline No. of Obs. & 217 & 217 & 217 & 217 & 217 & 217 \\
\hline
\end{tabular}

Note: in this specification, we test the role of share of R\&D expenditure in GDP and R\&D expenditure per person alternatively.

Graph 1: China's Growth pattern over 1960-2011

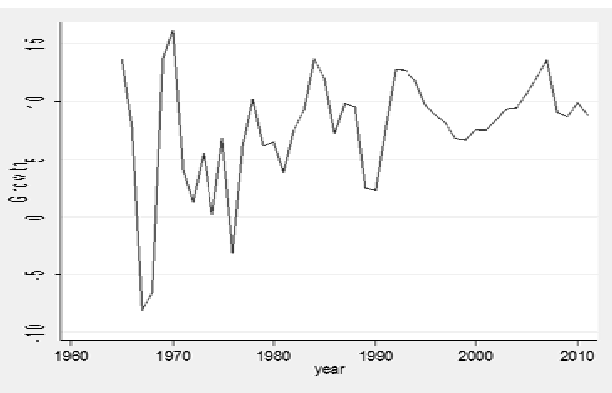

Graph 2: Export and Import shares in GDP over 1980-2011

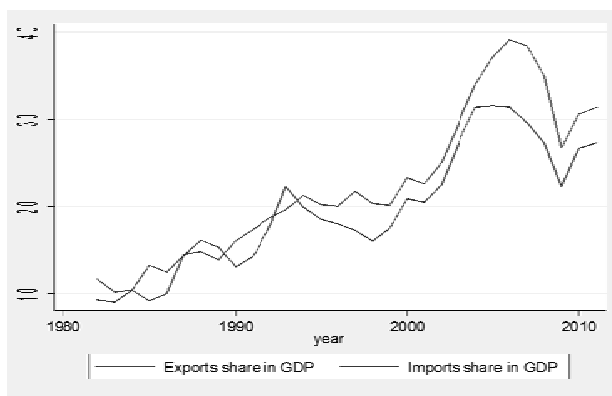


Business Review - Volume 8 Number 2

Graph 3: Growth, Gross Capital

formation and Savings over 1980-2011

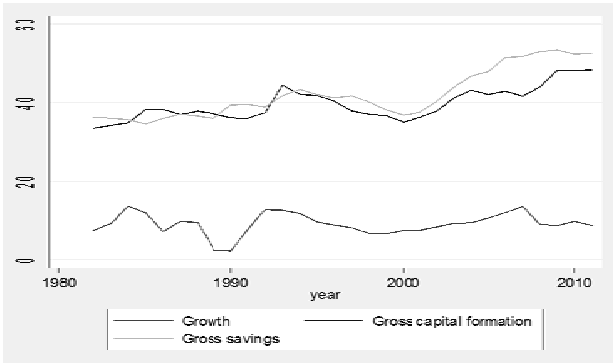

Figure 1: Identifying growth slow-down

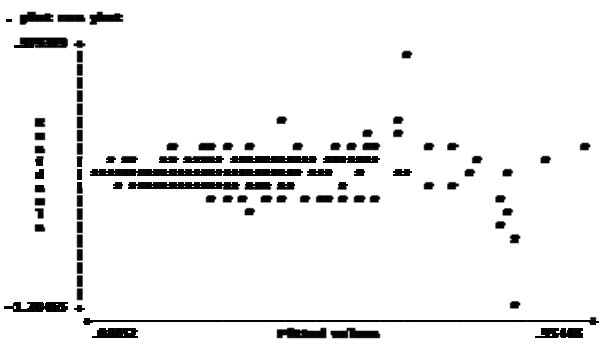

Figure 3: Per capita income and growth (2003-2011)

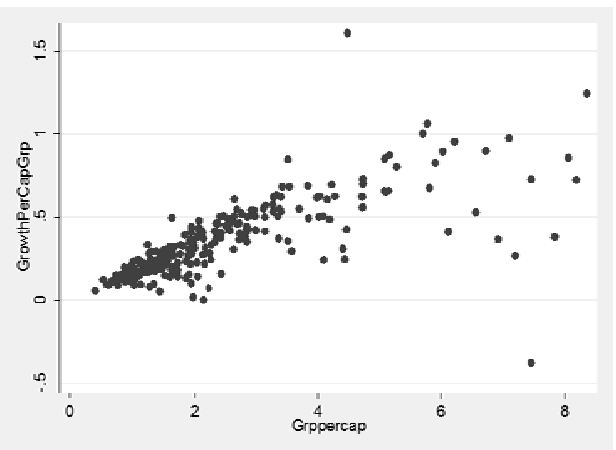

July - December 2013

Graph 4: Industrial value added and Agricultural value added over 1980-2011

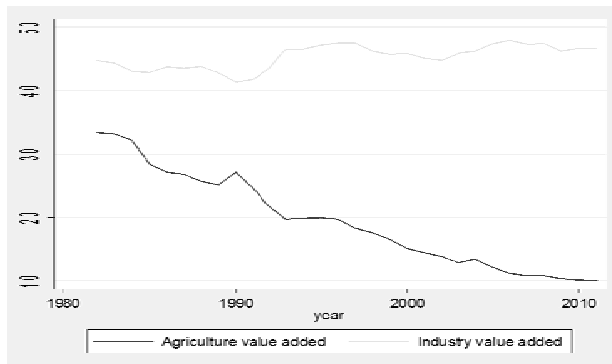

Figure 2: Relation between growth and lagged growth over 2003-2011

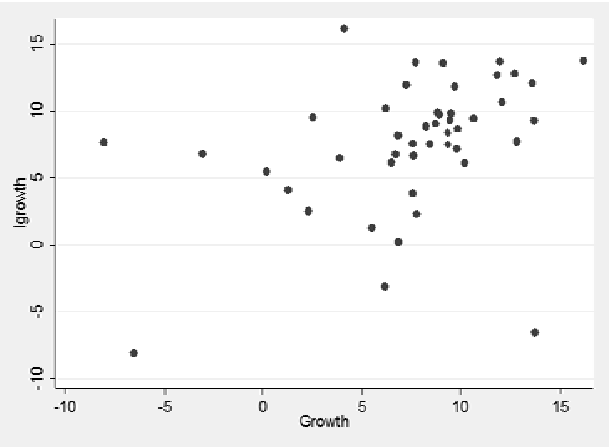

Figure 4: Per capita income and inventions

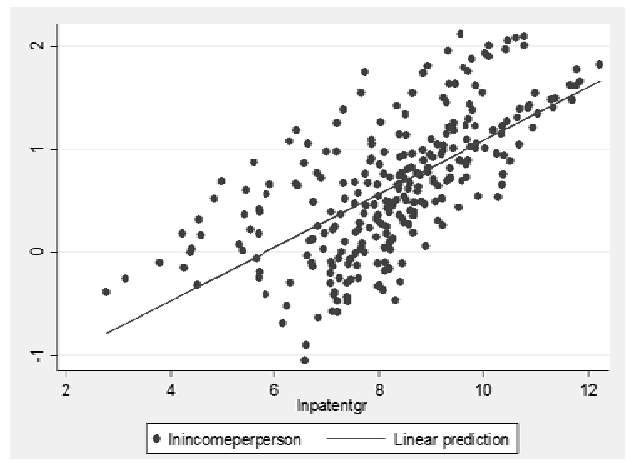


Figure 5: Per capita income and Higher education enrollment ratio

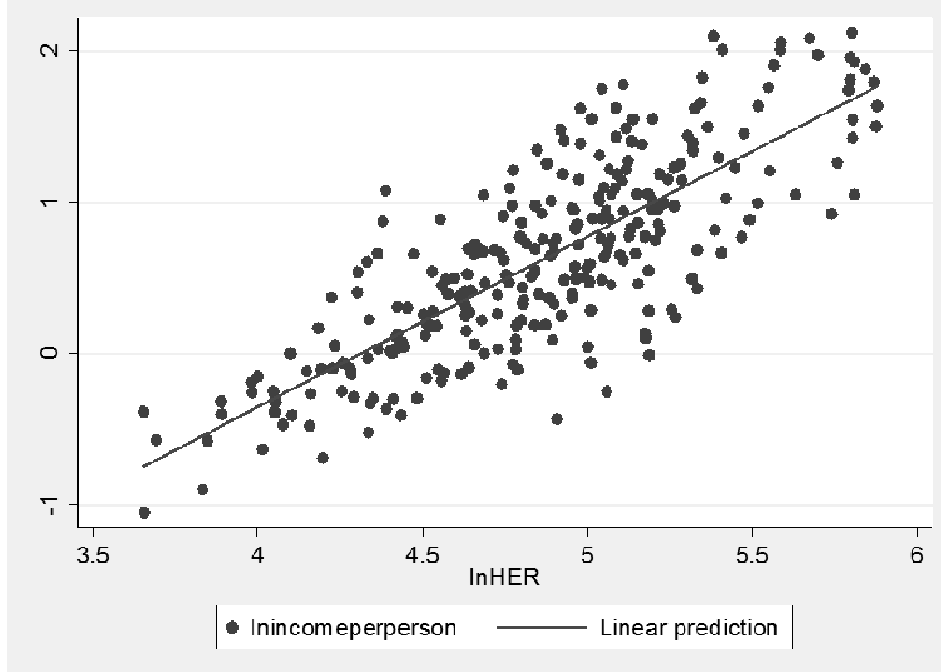

9

The mind that is much elevated and insolent with prosperity, and cast down by adversity, is generally abject and base.

\section{Epicurus}

